\title{
RELATION OF SELECTED FACTORS OF FURTHER EDUCATION IN ORGANIZATIONS DEVELOPMENT AND PROFITABILITY OF ORGANIZATIONS
}

\author{
Pavel PUDIL*, Irena MIKOVA, Lenka KOMARKOVA, Vladimir PRIBYL \\ Faculty of Management, University of Economics, Prague, \\ Jarosovska 1117/II, 377 01, Jindrichuv Hradec, Czech Republic \\ *E-mail:pudil@fm.vse.cz
}

\begin{abstract}
Purpose - further education and training play an important role in organizations development. The paper aims to analyze its relation to the financial performance of organizations, particularly to find which factors of further education are significantly related to the organization profitability indicators.

Research methodology - it is an empirical study based on 142 profit-oriented organizations operating in the Czech Republic. Multiple median regression was used to investigate the correlation among organization profitability and talent management, long-term strategy, education evaluation, investments into education, industry sector, organization size and its owner.

Findings - the results provide evidence that talent management, education evaluation, investments into education are significantly related to the considered profitability indicator ratios (ROA, ROE, ROCE, ROS).

Research limitations - follow from the size of the research sample, its extension is planned for the continuation of our research.

Practical implications - the results of the research could stimulate organizations to pay more attention to the key factors of further education in their development so as to improve their financial performance.

Originality/Value - the authors are not aware of any other empirical study from the post-transformation economies analyzing the relation of further education and the organization's financial performance. It extends our pilot study presented at ECMLG 2017 in London. The results provide a suggestion for organizations which steps to take in order to gain the most from further education.
\end{abstract}

Keywords: organization development, human resource management, further education, organizations profitability.

JEL Classification: I25, M21, M53, M54.

Conference topic: Contemporary Financial Management.

\section{Introduction}

Many definitions of organizational development (OD) can be found in the literature. What they all have in common is the goal of improving both the individuals and systems in the organization. The key role of OD is to realize purposeful change for the better. It also means to develop and implement practice dedicated to expanding the knowledge and effectiveness of people to accomplish more successful organizational change and performance. Exactly, this can be achieved in organizations by further education and training.

Therefore, though further education is usually considered to be a part of Human resource development (HRD), there is no doubt that further professional education and training plays an important role also in OD. Another supportive argument is that in the last years, the lines between HRD and OD have become somewhat blurred (Wride, 2017). Maylett and Wride (2017) also state that organizations with engaged workforces are more profitable, enjoy greater growth, and win the battle to keep the most talented personnel. Nowadays, successful organizations will be those that create for employees such an experience that helps them attract, retain, and engage the right talent.

A link between OD and Human resource management (HRM) is also discussed by T. G. Cummings and C. Cummings (2014). They state that OD draws on concepts and methods from other fields, among them from HRM. Furthermore, according to them, the field of OD has expanded enormously what has created some confusion and disagreement in defining the field's conceptual boundaries. 
To summarize, empirical research in the field of HRM, particularly in further education, is certainly aimed within the boundaries of OD. The objective of our research is to investigate the importance of further education for the successful performance of organizations. Moreover, it concerns also the relationship between other education indicators (talent management, education evaluation, investments into education) or organization characteristics (industry sector, organization size, and its owner) and the organization profitability.

\section{Current state of knowledge}

The prosperity and successfulness of any organization are influenced by a large number of factors. The fact of whether further professional education is or is not incorporated into the organization's long-term strategy is certainly one of those factors. According to Armstrong (2006), professional education should be an integral part of the management process in any organization. HRM is defined as a strategic and logically thought-out approach to managing the most valuable asset that organizations have - people working in the organization and contributing to the achievement of the organization objectives.

Koubek (2008) writes about HRD as a part of HRM. He designated HRD in that time as a new concept of education and organization development. While educational and development activities were aimed mainly at the development of an individual employee in the traditional concept of personal agenda, in the framework of development activities they are oriented towards the development of capabilities of the organization as a whole. They are linked to the effectiveness of activities and performance of the whole organization or the learning organization. Hroník (2007) defines the concept of development using the concept of learning as "achieving the desired change by learning".

There are several models for evaluating the effectiveness of professional education in organizations, e.g. Hamblin's (1974), Simmonds's (2003) and Kirkpatrick's model (e.g. Kirkpatrick \& Kirkpatrick, 2006). Especially the last one is very often used for education/training evaluation (e.g. Tenkl, 2014; Pituchová, 2013). It is aimed at preparing and realizing education and development activities so as to have a measurable effect. It has four levels (reaction, learning, behaviour, and results) and is considered as a standard of evaluating education in HRM. Kirkpatrick's model evaluates the quality of education processes; however, it does not evaluate financial benefits resulting from education processes. The shortcoming of Kirkpatrick's model concerning the evaluation of financial benefits for the organization has been remedied by Phillips (1996). Phillips's proposal, sometimes denoted as the Kirkpatrick/Phillips's model considers extending the original Kirkpatrick's model by one level. Particularly, the fifth level of the model added looks at the return on investments (ROI) which indicates whether the investments into further education will pay off. This financial indicator can be applied even to the field of education; however, bearing in mind that not all items can be materially expressed.

The research concerning further education is rather extensive. Some authors investigated the impacts of further education on employees participating in this education (e.g. Isaksson, Garvare, Johnson, Kuttainen, \& Pareigis, 2015; Khan, 2012). Other authors (e.g. Matlay, 2008) focused their research on entrepreneurial outcomes and a change of attitudes resulting from special education and training.

Another research direction, which corresponds to our research objectives, concerns the effects of education, specifically the impact of further education on organizations performance. Rahimić and Vuk (2012) discussed the use of Kirkpatrick's model and argued that the level of evaluation should depend on the final goals of training/education. Sutherland (2016) examined the relationship between learning and innovation. He stated that linking HRM and innovation helps to understand the contribution of learning and innovation to economic success. A multiple-regression model was used by Chen, Chang, and Lee (2008). They identified a significant relationship between external training and financial performance, however, only for large size companies. An interesting issue of the impact of training on employee retention was investigated by Beynon, Jones, Pickernell, and Packham (2015). A positive effect of education and training programmes on the productivity measured by business per employee at the selected Indian banks was found by Kaur (2016). Also, Van de Wiele (2010) confirmed the positive impact of current training on future firm performance using a large sample of firms in Belgium. On the other hand, rather interestingly, Barrett and O'Connell (2001) did not find a significant influence of training costs on firm performance for companies in Ireland.

As a result of changes in the environment related to globalization, technological development and demographic development, flexibility and adaptability are the preferred competencies not only for workers themselves but also for companies as a whole. In order for companies to maintain their position on the market, they must constantly follow new trends, and they ask for increased investment in development and, in particular, innovations, into human capital, which can rightly be considered the main source of innovation (Urbancová, Vnoučková, \& Smolová, 2016). The goal of the organization is, therefore, the effort to get creative and talented employees. In the event that these employees have an organization, it is the goal of setting up corporate processes and development programs in such a way that these employees are motivated and stay in the organization for a long time.

One of the driving forces contributing to the success of organizations in recent years is considered to be the strategic concept of talent management. However, as mentioned by Egerova, Eger, and Jirincova (2013), this theme is not a novelty of recent times, but attention has been paid to it since the 1980s. She draws attention to the fact that despite the increasing importance of talent management, it turns out that in practice many organizations do not 
implement this concept effectively. The reasons may be an insufficient theoretical definition of the issue, including the definition of the basic concepts of talent and talent management. To explore the issue of talent management and care for them in organizations, it is also essential to identify the most frequent reasons why some organizations have a relatively small interest in talent management. Urbancová et al. (2016), and Stacho, Stachová, and Gubínková (2016) conclude that among the reasons is not the perception of the importance of this issue, the ignorance of the talent management concept, the costs and time, and finally the implementation difficulty of introducing a new system.

With the development of a knowledge-based society, talent management has become a priority for the top management of organizations. Baartvedt (2013), based on a case study, provides a detailed insight into the implementation of talent management in a particular multinational company. Talent management and development in emerging market economies is discussed by Dirani and Nafukkho (2018).

Nikandrou, Apospori, Panayotopoulou, Stavrou, and Papalexandris (2008) focused on the relationship between training and development and performance, based on the CRANET project data. Though somewhat outdated (especially taking into account that the sample data are prior to 2008), it provides an interesting approach by combining national and organizational factors through a hierarchical linear model to explore the training and development and performance relationship in 14 European countries. The main findings point out the importance of cultural, institutional and organizational factors in analyzing the relationship between training and development and performance.

From all these studies we can state that the existence of further education in organizations certainly belongs among the factors influencing their financial performance. In our pilot study (Pudil, Komarkova, \& Mikova, 2017) conducted in 2016, we investigated a statistical dependence of ROA on two factors, namely on investments in education and on impacts education evaluation, though owing to a small sample size (40 organizations) the trends could not have been found as statistically significant.

In this study based on new data from 2017, therefore, we expanded 1/ the number of organizations, 2 / the number of factors studied and $3 /$ the number of financial indicators. Its results contribute to the current state of knowledge, particularly with respect to confirming statistically significant relations between increased investments to further education and evaluating its effects on the one hand, and financial indicators of organization on the other.

\section{Data set and methods used in the study}

\subsection{Data}

In order to pursue our research goal, formulated in the Introduction, data from for-profit organizations operating in the Czech Republic were collected using an anonymous questionnaire, conducted online in 2017. We received a total of 550 responses. The respondents participated voluntarily and absolutely no inducements were applied, only a personal letter was sent to all former graduates asking them to help with the research carried out at their former faculty.

This study included companies with a total of 10 or more employees (ie without micro companies). Though the research sample was much bigger, we could have used only those organizations, for which the data about financial performance for the year 2017 were available. The final research sample consisted of 142 for-profit organizations operating in the secondary and tertiary sectors, i.e. without the primary sector covered by two NACE sectors A Agriculture, Forestry and Fishing; B - Mining. In summary, this sample includes 102 companies more than the sample in the pilot study (Pudil et al., 2017) based on data from the previous year.

\subsection{Methods used}

The relation between the financial performance of organizations and the selected characteristics of these organizations was investigated by means of multiple regression. Since the considered financial indices have outliers, multiple median regression instead of standard multiple linear regression has been used. The analysis was conducted in the statistical software R version 3.5.2 (R Core Team, 2018) using R-package quantreg.

\section{Variables}

Several financial ratio indices for 2017 (indicator values are expressed as a percentage) were used as a dependent variable $\mathrm{Y}$ for the multiple median regression model. From a number of financial ratio indices we have acquired from the Albertina database the following ones for the analysis:

ROA (Return on Assets, Return on Total Capital) is a frequently used indicator of how profitable a company is relative to its total assets. ROA gives a manager, investor, or analyst an idea as to how efficient a company's management is at using its assets to generate earnings.

- ROE (Return on Equity) is a measure of financial performance calculated by dividing net income by shareholders' equity. Because shareholders' equity is equal to a company's assets minus its debt, ROE could be thought of as the return on net assets.

- ROCE (Return on Capital Employed) complements the return on equity (ROE) ratio by adding a company's debt liabilities, or funded debt, to equity to reflect a company's total "capital employed". This 
measure narrows the focus to gain a better understanding of a company's ability to generate returns from its available capital base. It is closest to ROI.

- ROS (Return on Sales), also known as a firm's operating profit margin, is a ratio used to evaluate a company's operational efficiency. This measure provides insight into how much profit is being produced per dollar of sales. An increasing ROS indicates that a company is growing more efficiently, while a decreasing ROS could signal impending financial troubles.

The questionnaires provided data concerning the following explanatory variables (predictors) for the model:

Talent - Special Education for Talents (Yes / No);

Evaluation - Traning and Education Evaluation (Yes / No);

Investment - Degree of Investments in Education (Lower / Higher);

Sector - Sector of the Economy (Secondary - manufacturing and industry / Tertiary - trade and services);

Size - Enterprise Size concerning the number of employees (Small and Medium Enterprises SME: 10-49

employees / Large Enterprises: 250 and more employees);

Owner - Majority Owner of the company (Domestic / Foreign).

Notice that all the considered predictors are dichotomous variables.

\section{Results}

A basic descriptive statistics concerning the absolute and relative frequencies of the types of organizations concerning the values of selected characteristics (variables) are given in Table 1. Other statistics characterizing the selected financial ratio indices (mean, lower and upper quartile) are given for individual variables in Table 2. Note that all the organization characteristics are dichotomous variables as they attain two values only. The meaning of "Value" is either obvious or it is explained above in the Variables section.

Table 1. Absolute and relative frequencies of the types of organizations concerning the values of selected characteristics

\begin{tabular}{|c|c|c|c|c|c|c|}
\hline \multirow{2}{*}{$\begin{array}{c}\text { Organization type with } \\
\text { respect to selected } \\
\text { characteristics }\end{array}$} & Talent & Evaluation & Investment & Sector & Size & Owner \\
\cline { 2 - 7 } & Yes & yes & higher & tertiary & large & foreign \\
\cline { 2 - 7 } & no & no & lower & secondary & small & domestic \\
\hline \multirow{2}{*}{ Number } & $36(25.4 \%)$ & $122(85.9 \%)$ & $69(48.6 \%)$ & $96(67.6 \%)$ & $73(51.4 \%)$ & $89(62.7 \%)$ \\
\cline { 2 - 7 } & $106(74.6 \%)$ & $20(14.1 \%)$ & $73(51.4 \%)$ & $46(32.4 \%)$ & $69(48.6 \%)$ & $53(37.3 \%)$ \\
\hline
\end{tabular}

Table 1 shows that only about one-quarter of all the investigated organizations have implemented special education and training for talents, that is the talent management program. This corresponds to the findings of Urbancová et al. (2016) and Stacho et al. (2016) as mentioned in the Current State of Knowledge section. Contrary, it can be seen that organizations are aware of the importance of further education evaluation. In particular, only $14 \%$ of organizations do not evaluate the effects of further education. A study by Pudil et al. (2017) found that investing more financial means in further education while not evaluating its effects may lead to ineffective use of investments. One of the reasons is in using not effective methods of further education and under the absence of its evaluation. $49 \%$ of organizations included in the sample investment into their employees' education relatively enough. In the view of organization's characteristics, the sample included more large enterprises than SMEs; more organizations with foreign than domestic founder; and more organizations form the tertiary sector in contrast to the secondary sector of the economy.

Table 2 indicated that financial results are better for organizations without special education for talents; with evaluation of education; with higher investments in further education; from the tertiary sector; and with the foreign owner. In the case of organizations size, large organizations have median values of financial indicators greater for ROA and ROCE and lower for ROE and ROS in comparison with SMEs. However, these results are only informative because the differences are not tested and moreover, they are not adjusted for the effects of the other five dichotomous variables.

Table 2. Median (lower, upper quartile) for selected financial indices (in \%) according to organization characteristics

\begin{tabular}{|c|c|c|c|c|c|}
\hline Variable & Value & ROA & ROE & ROCE & ROS \\
\hline Talent & No & $8.5(2.3,17.4)$ & $21.0(7.1,38.6)$ & $12.8(4.9,32.4)$ & $4.2(0.9,8.4)$ \\
\hline & Yes & $5.8(3.9,13.0)$ & $14.9(7.6,42.1)$ & $12.1(5.8,38.8)$ & $3.2(1.9,7.9)$ \\
\hline Evaluation & No & $3.6(1.1,6.1)$ & $9.9(0.5,24.4)$ & $7.9(0.5,12.2)$ & $1.4(0.4,4.8)$ \\
\hline & Yes & $8.5(3.3,17.0)$ & $21.8(7.7,42.1)$ & $16.6(5.8,34.3)$ & $4.3(1.8,8.5)$ \\
\hline
\end{tabular}




\begin{tabular}{|l|c|c|c|c|c|}
\hline Variable & Value & ROA & ROE & ROCE & ROS \\
\hline Investment & Lower & $6.4(1.8,12.7)$ & $17.3(5.7,32.6)$ & $10.2(4.4,23.4)$ & $3.7(0.7,7.8)$ \\
\hline & Higher & $8.5(4.6,18.7)$ & $24.1(9.5,49.7)$ & $19.7(6.8,38.2)$ & $4.2(2.2,8.8)$ \\
\hline Sector & Secondary & $6.1(2.7,11.9)$ & $13.5(6.8,33.6)$ & $11.7(5.9,28.1)$ & $2.9(1.5,7.1)$ \\
\hline & Tertiary & $8.5(2.3,18.4)$ & $21.6(7.3,44.9)$ & $13.9(4.8,36.7)$ & $4.2(1.5,9.1)$ \\
\hline Size & Small/middle & $6.8(1.9,18.7)$ & $20.8(5.7,55.5)$ & $11.5(4.4,38.2)$ & $4.0(0.7,9.1)$ \\
\hline & Large & $8.3(3.9,12.7)$ & $20.3(9.5,34.9)$ & $14.2(7.3,28.1)$ & $3.8(2.0,7.4)$ \\
\hline Owner & Domestic & $4.9(1.3,11.0)$ & $9.9(5.1,32.6)$ & $8.0(3.9,32.1)$ & $2.3(0.4,6.2)$ \\
\hline & Foreign & $9.5(4.3,17.0)$ & $25.1(9.5,40.1)$ & $17.1(7.6,33.6)$ & $5.1(2.2,8.8)$ \\
\hline
\end{tabular}

In order to analyze the relationship of explanatory variables with financial ratio indices, multiple median regression model was used. It means that the model is for the median of dependent variable Y, where Y denotes the individual financial ratio index. The results of multiple median regression for all the considered variables together are given in Table 3. Effect estimates (Est) and p-values of related significant effect tests can be found here.

Table 3. Multiple median regression (model for a median of variable Y) - for all the variables together

\begin{tabular}{|l|c|c|c|c|c|c|c|c|}
\hline & \multicolumn{2}{|c|}{ ROA } & \multicolumn{2}{c|}{ ROE } & \multicolumn{2}{c|}{ ROCE } & \multicolumn{2}{c|}{ ROS } \\
\hline \multicolumn{1}{|c|}{ Variable } & Est & $\mathrm{p}$ & Est & $\mathrm{p}$ & Est & $\mathrm{p}$ & $\mathrm{Est}$ & $\mathrm{p}$ \\
\hline Talent & -3.72 & $\mathbf{0 . 0 2 3}$ & -6.12 & 0.386 & -5.57 & 0.409 & -1.46 & 0.199 \\
\hline Evaluation & 5.35 & $\mathbf{0 . 0 0 4}$ & 5.40 & 0.183 & 5.01 & 0.245 & 1.82 & $\mathbf{0 . 0 1 9}$ \\
\hline Investment & 1.63 & 0.289 & 9.53 & $\mathbf{0 . 0 3 4}$ & 8.16 & $\mathbf{0 . 0 4 0}$ & 0.92 & 0.276 \\
\hline Sector & 0.56 & 0.697 & 0.82 & 0.814 & -0.24 & 0.943 & 0.37 & 0.647 \\
\hline Size & -0.98 & 0.599 & -4.61 & 0.297 & -0.85 & 0.845 & -0.92 & 0.302 \\
\hline Owner & 3.59 & $\mathbf{0 . 0 3 2}$ & 9.86 & $\mathbf{0 . 0 0 3}$ & 7.06 & $\mathbf{0 . 0 4 9}$ & 2.30 & $\mathbf{0 . 0 0 8}$ \\
\hline
\end{tabular}

The statistically significant results (at the 5\% significance level) are denoted in bold. From these results, we can see that 4 out of all 6 considered explanatory variables have a statistically significant relation with at least one of the financial ratio indices (adjusted always for the effects of the remaining five explanatory variables). In summary, they are:

Owner - with ROA, ROE, ROCE, ROS (with ROE and ROS even at the $1 \%$ level),

Evaluation - with ROA, ROS (with ROA even at the $1 \%$ level),

Investment - with ROE, ROCE,

Talent - with ROA.

The remaining variables, namely Sector and Size, were found not to have a statistically significant relationship with any of the financial ratio indices. It is worthy noting that all the statistical significant relations are positive ones except the variable Talent where the relationship was found as the negative one in the case of ROA. As far as other financial indices are concerned, no significant relation with Talent was found. All these findings are discussed in more detail in the following section, together with a rather surprising negative relationship between the variables Talent and ROA.

\section{Discussion of results}

Prior to discussing the results presented above, we should stress that the use of the expression "relation" instead "influence", e.g. "a significant relation between Investment and ROE" instead "positive influence of Investment on ROE" is intentional. The reason is that we cannot always unambiguously determine the direction of causality. Just for example, though we may in accordance with the number of authors, among them e.g. Morley, Slavic, Poór, and Berber (2016), Urbancová et al. (2016), assume that a higher investment into further education of employees' results in better financial performance of the organization, the following question can be naturally raised:

Cannot it be true that the organizations with better financial performance can afford to invest higher financial means into further education of their employees?

This argumentation would, of course, mean the opposite direction of causality. A similar argumentation can be in our opinion also valid in the case of the existence of talent management and financial performance. Though the above-named authors (and many others) argue the importance and positive impacts of implementing special programs for talent management, the results of our empirical research provide perhaps surprisingly a different result. While no 
statistically significant relation of talent management with ROE, ROCE, ROS was found, the relationship between the existence of talent management and ROA is statistically significant $(p=0.023)$ and mainly negative.

We have certainly no doubts about the importance of further education and talent management, and in principle agree with all these authors. Nevertheless, in the endeavour to explain this perhaps surprising result of a negative relation, we suggest the following possible explanation. In accordance with the above stated necessary caution concerning the direction of causality, we should be very cautious to interpret this result as a negative influence of implementing talent management programs on ROA of the organization. Though we are aware of not having any unquestionable evidence for the following views, the reasons may be quite different.

In the last years in many countries (particularly in post-transformation economies as the Czech Republic) the originally higher unemployment rate has dramatically decreased. Demographic changes, globalization and especially the anticipated generation shift in the labour market also affect organizations. This situation requires reconsideration of existing approaches to the acquisition, development and retaining of talented employees. As Baartvedt (2013) stated, researchers predicted that there would be a shortage of workforce due to retirement in the coming years. This prediction is becoming true. Nowadays, companies and organizations have difficulties to find on the labour market sufficiently qualified people they would either need to remain competitive and successful or to become more successful and competitive in the case they are not now. Such qualified people are often simply not available.

The organizations are well aware of this fact. As already stated in the introduction, with the development of a knowledge-based society, talent management has become a priority for the top management of organizations. The key to the competitive advantage of organizations is then business strategies linked with talent management processes. The long-term sustainability of an organization depends on human capital, that is, to have the right people in the right places. If organizations are not currently too successful, they need to acquire qualified people. However, when such qualified people cannot be found in the labour market, these organizations have to raise them and therefore they implement talent management. On the other hand, successful organizations with high ROA do not feel any urgent need to introduce talent management because they already have highly qualified staff. They rather prefer to devote resources to retaining their employees by various benefits, by improving the working environment, etc. We are aware that this is a somewhat speculative view, but with a rational core. In future research, we intend to verify it by means of qualitative research (interviews with managers, etc.).

As far as the results concerning other characteristics of further education are concerned, some of them were found to be related to the performance of the organization, while some of them not (at least not significantly). This is in accordance with the results of other authors who found a positive relation, e.g. Rahimić et al. (2012), Sutherland (2016), Chen et al. (2008), Kaur (2016), Van de Wiele (2010). On the other hand, other studies reported finding no significant influence. Barrett et al. (2001) reported no significant influence of training costs on firms performance in Ireland. Karadag (2017) found no significant difference in SMEs operating in different industries. Based on their study, Dermol and Cater (2013) state that the volume and quality of training are related only to the acquisition and interpretation of information, while no direct relationship with company performance was found.

Positive relations of the type of owner, evaluation of education and the level of investments into further education are in accordance with our previous research. Our pilot study (Pudil et al., 2017) clearly indicated that trends relating the investment in further education and evaluating its impacts on the one hand and the financial performance measured through ROA on the other, exist. Though the statistical significance of these trends could not have been proved due to the small size of the research sample, the results suggest that investment in further education is only meaningful with simultaneous evaluation of the effectiveness of this education.

The fact that higher investments in further education should be accompanied by evaluating its effects and impacts not just on the employees but also on the business companies is in accordance with our recent result. In the just above named study we also demonstrated that business companies and organizations evaluating impacts of further education used much more often methods that were considered by participants of education and training as more effective. In the opposite case they tend not to use the most effective methods of learning and, therefore, are actually not making the most of the financial means they devoted to the further education and training of their employees.

In another study, based on the research sample of 124 organizations (Mikova, Komarkova, \& Pudil, 2017), we found out that companies perceived the impacts of further education, above all in terms of better service quality, change in employees behaviour and the possibility of self-development. The impact on performance reflected in higher sales was the fourth in ranking. The study (Mikova, Komarkova, Pudil, \& Pribyl, 2018) has shown that the type of foreign ownership of companies (foreign or domestic owners) is related to further education and training. Based on the results of the Pearson chi-squared tests of independence, the statistically significant differences in using so-called modern approaches to further education and training were found.

Finally, no relationship between the financial ratio indices and the sector or the organization size has been found in the current study. 


\section{Conclusions}

To conclude, the results of this study are certainly not in contradiction with the findings of the authors mentioned above. The variables Owner, Evaluation, and Investment have a statistically significant relationship (a positive one) with at least two of the financial ratio indices. On the other hand, no such statistically significant relationship was found in the case of the economic sector and the size of the organization. This finding is again in accordance with other authors, e.g. Dermol and Cater (2013).

Finally, though our study found a negative relation of talent management and ROA, it certainly does not question the claims of Morley et al. (2016), Urbancová et al. (2016), Baartvedt (2013), Egerova et al. (2013), and other authors about the importance of further education and talent management particularly, for the success of organizations. As discussed more thoroughly in the previous section, a seemingly straightforward interpretation that the companies should not invest in talent management would be too simplified and according to our opinion not correct. It should be looked upon having in mind the issue of the direction of causality. In the previous section, we argued and presented some explanation that successful organizations may not feel any need to organize and invest in talent management. On the contrary, less successful organization with worse values of ROA may feel the necessity to build talent management so as to bring up needed qualified employees. To conclude, we interpret this seemingly negative result so that talent management is for organizations really important and that is why those organizations that are not successful, introduce it more often.

The results of the study provide suggestions for organizations which steps they should take with respect to HRM, and to further education, in particular, to improve their financial indicators. They demonstrate that particularly increasing investments into further education and training is related to higher values of financial indicators. Another valuable contribution is in the finding of the importance of evaluating the effects of further education and training. The positive relation between evaluating these effects and ROA has been confirmed even at the $1 \%$ level of significance. This is in accordance with the results of a pilot study (Pudil et al., 2017) based, however on a smaller sample. That pilot study suggested that increasing relative investments into further education alone, without evaluating its effects at the same time, might not bring the required positive impacts at all. Therefore, evaluating the effects of further education can be considered as necessary (if not imperative) prerequisite in order to achieve better financial performance.

\section{Limitation of research and its future direction}

Limitation of our results follows from the fact that it concerns only the companies and organization operating in the Czech Republic and thus the sample size is restricted. In future research, we plan to extend the sample size and include also organizations from abroad. Furthermore, as already stated, we intend to complement our results by means of qualitative research.

\section{Funding}

This work was supported by the Czech Science Foundation (GA CR) under Grant [number 18-01159S].

\section{Disclosure statement}

Authors declare that they have no competing financial, professional, or personal interests from other parties.

\section{References}

Armstrong, M. (2006). A handbook of human resource management practice. Kogan Page Publishers.

Baartvedt, N. (2013). Talent management as a strategic priority for competitive advantage.: A qualitative case study on talent management implementation within a Multinational Company (Dissertation). Retrieved from http://urn.kb.se/resolve?urn=urn:nbn:se:umu:diva- 86472

Barrett, A., \& O'Connell, P. J. (2001). Does training generally work? The returns to in-company training. ILR Review, 54(3), 647662. https://doi.org/10.1177/001979390105400307

Beynon, M. J., Jones, P., Pickernell, D., \& Packham, G. (2015). Investigating the impact of training influence on employee retention in small and medium enterprises: a regression-type classification and ranking believe simplex analysis on sparse data. Expert Systems, 32(1), 141-154. https://doi.org/10.1111/exsy.12067

Cummings, T. G., \& Cummings, C. (2014). Appreciating organization development: A comparative essay on divergent perspectives. Human Resource Development Quarterly, 25(2), 141-154. https://doi.org/10.1002/hrdq.21186

Chen, Y. S., Chang, B. G., \& Lee, C. C. (2008). The association between continuing professional education and financial performance of public accounting firms. The International Journal of Human Resource Management, 19(9), 1720-1737. https://doi.org/10.1080/09585190802295363

Dermol, V., \& Cater, T. (2013). The influence of training and training transfer factors on organisational learning and performance. Personnel Review, 42(3), 324-348. https://doi.org/10.1108/00483481311320435 
Dirani, K. M., \& Nafukho, F. M. (2018). Talent management and development: Perspectives from emerging market economies. Advances in Developing Human Resources, 20(4), 383-388. https://doi.org/10.1177/1523422318803362

Egerova, D., Eger, L., \& Jirincova, M. (2013). Integrated talent management: Challenge and future for organizations in Visegrad Countries. Plzen: NAVA.

Hamblin, A. C. (1974). Evaluation and control of training (1st ed.). London: McGraw-Hill.

Hroník, F. (2007). Rozvoj a vzdělávání pracovníků [Employee development and education]. Praha: Grada Publishing.

Isaksson, R., Garvare, R., Johnson, M., Kuttainen, C., \& Pareigis, J. (2015). Sustaining Sweden's competitive position: lean lifelong learning. Measuring Business Excellence, 19(1), 92-102. https://doi.org/10.1108/MBE-11-2014-0045

Karadag, H. (2017). The impact of industry, firm age and education level on financial management performance in small and medium-sized enterprises (SMEs) evidence from Turkey. Journal of Entrepreneurship in Emerging Economies, 9(3), 300314. https://doi.org/10.1108/JEEE-09-2016-0037

Kaur, J. (2016). Impact of training and development programmes on the productivity of employees in the banks. Journal of Strategic Human Resource Management, 5(1), 47-53. https://doi.org/10.21863/jshrm/2016.5.1.023

Khan, M. I. (2012). The impact of training and motivation on performance of employees. IBA Business Review, 7(2), 84-95.

Kirkpatrick, D. L., \& Kirkpatrick, J. D. (2006). Evaluating training programs: The four levels. San Francisco: Berrett-Koehler Publishers.

Koubek, J. (2008). Řizení lidských zdrojů: základy moderní personalistiky [Human resource management: foundations of modern personnel management] (4th ed.). Praha: Management Press.

Matlay, H. (2008). The impact of entrepreneurship education on entrepreneurial outcomes. Journal of Small Business and Enterprise Development, 15(2), 382-396. https://doi.org/10.1108/14626000810871745

Maylett, T., \& Wride, M. (2017). The employee experience: How to attract talent, retain top performers, and drive results. John Wiley \& Sons.

Mikova, I., Komarkova, L., \& Pudil, P. (2017). Relation between usage of more effective methods of lifelong learning and evaluating its impacts. In Conference Proceedings: 11th International Technology, Education and Development Conference (INTED), International Academy of Technology, Education and Development, Valencia (pp. 963-970). https://doi.org/10.21125/inted.2017.0380

Mikova, I., Komarkova, L., Pudil, P., \& Pribyl, V. (2018). Effectiveness of professional development and training with respect to the scope of company activities and ownership. In International Conference on Management, Leadership \& Governance (pp. 203-211). Academic Conferences International Limited.

Morley, M. J., Slavic, A., Poór, J., \& Berber, N. (2016). Training practices and organisational performance: A comparative analysis of domestic and international market-oriented Organisations in Central \& Eastern Europe. JEEMS Journal of East European Management Studies, 21(4), 406-432. https://doi.org/10.5771/0949-6181-2016-4-406

Nikandrou, I., Apospori, E., Panayotopoulou, L., Stavrou, E. T., \& Papalexandris, N. (2008). Training and firm performance in Europe: the impact of national and organizational characteristics. The International Journal of Human Resource Management, 19(11), 2057-2078. https://doi.org/10.1080/09585190802404304

Phillips, J. (1996). How much is the training worth? Training and Development, 50(4), 20-24.

Pituchová, I. (2013). Evaluation of the corporate education using the Kirkpatricks Model. Acta academica karviniensia,13(2), 8493. https://doi.org/10.25142/aak.2013.028

Pudil, P., Komarkova, L., \& Mikova, I. (2017, December). Link between financial performance of organizations and selected aspects of further education. In European Conference on Management, Leadership \& Governance (pp. 402-407). Academic Conferences International Limited.

Rahimić, Z., \& Vuk, S. (2012). Evaluating the effects of employees education in B\&H companies. In E. Mehic (Ed.), Conference Proceedings: 6th International Conference of the School of Economics and Business (ICES) "Beyond the economic crisis: lessons learned and challenges ahead", Sarajevo, 12-13.10.2012 (pp. 1044-1057).

R Core Team. (2018). R: A language and environment for statistical computing. Vienna: R Foundation for Statistical Computing, Vienna. Retrieved from: https://www.r-project.org/

Simmonds, D. (2003) Designing and delivering training. London: Chartered Institute of Personnel and Development.

Stacho, Z., Stachová, K., \& Gubínková, K. (2016). Využitie talent manažmentu ako motivácie pre zamestnancov s vysokým pracovným potenciálom. In 13th International Scientific Conference Human Potential Development, 2016.

Tenkl, M. (2014). Kirkpatrickův čtyř-úrovňový model: teorie, praktické využití a možná úskalí [Kirkpatrick’s Four-level Model: Theory, Practical Application and Possible Difficulties]. Evaluační teorie a praxe, 2(1), 23-51.

Urbancová, H., Vnoučková, L., \& Smolová, H. (2016). Talent management v organizacích v České republice. Praha: Odborné nakladatelství VŠEM.

Van de Wiele, P. (2010). The impact of training participation and training costs on firm productivity in Belgium. The International Journal of Human Resource Management, 21(4), 582-599. https://doi.org/10.1080/09585191003612083

Wride, M. (2017). What's the difference between human resources and organizational development? Retrieved from: https://www.decision-wise.com/difference-between-human-resources-and-organization-development/ 